\title{
INCIDENTAL CATCHES OF FRANCISCANA (PONTOPORIA BLAINVILLEI) ON THE SOUTHERN COAST OF SÃO PAULO STATE AND THE COAST OF PARANÁ STATE, BRAZIL
}

\author{
Fernando C. Weber Rosas ${ }^{1,}$, Emygdio L. A. Monteiro-Filho² and Márcia R. de Oliveira ${ }^{3}$
}

\begin{abstract}
A total of 40 individuals of P. blainvillei, incidentally caught on the southern coast of São Paulo State (region of

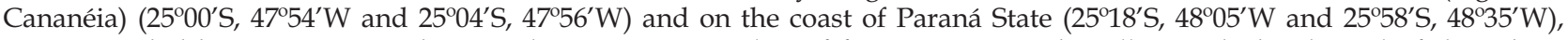
were recorded between 1997 and 1999. The average mortality of franciscanas incidentally caught by the only fishing boat sampled on the southern coast of São Paulo State, which operated up to 40 nautical miles (nm) from the coast, was 11 individuals/ year, with a proportion of 2.3 males for every female. An average mortality of 10 franciscanas/year was estimated for several artisanal fishing communities sampled on the coast of Paraná State, where fishing activities usually are not further than $5 \mathrm{~nm}$ from the coast. There was no significant difference $(\mathrm{P}>0.05)$ between the proportion of males and females incidentally caught by the artisanal fisheries on the Paraná coast. The proportion of sexually immature franciscanas reached $55 \%$ in southern São Paulo State, compared with $76.2 \%$ for the coast of Paraná. Bottom-set gillnets, with a stretched mesh size of 7.0 and $13.0 \mathrm{~cm}$, recorded the greatest number of individuals incidentally caught in the Cananéia region. However, on the Paraná coast, the greatest number of franciscanas was incidentally caught in driftnets with a stretched mesh size of $10.0 \mathrm{~cm}$. Comparing these mesh sizes with those presented in the literature for franciscanas incidentally caught in other places, it seems that other fishery characteristics (e.g. distance from the coast, depth, fishing effort, and season) are more important than the mesh size itself. The predominance of captured males in the fisheries further away from the coast, and the greatest proportion of sexually immature franciscanas incidentally caught in the fisheries closer to the coast, suggest spatial segregation between some age groups and sexes for this species in the study area. The results also suggest that the fisheries with industrial fishing characteristics, carried out by the boats in the Cananéia region, could be causing a strong impact on the populations of $P$. blainvillei. This means that a continuous surveillance of fishing activity is necessary for a greater period, including as many boats as possible, in order to certify the mortality estimates in that region.
\end{abstract}

Resumo - Um total de 40 exemplares de P. blainvillei acidentalmente capturados no litoral sul do Estado de São Paulo (região de Cananéia) $\left(25^{\circ} 00^{\prime} \mathrm{S}, 47^{\circ} 54^{\prime} \mathrm{W}\right.$ e $\left.2^{\circ} 04^{\prime} \mathrm{S}, 47^{\circ} 56^{\prime} \mathrm{W}\right)$ e litoral do Estado do Paraná ( $25^{\circ} 18^{\prime} \mathrm{S}, 48^{\circ} 05^{\prime} \mathrm{W}$ e $\left.25^{\circ} 58^{\prime} \mathrm{S}, 48^{\circ} 35^{\prime} \mathrm{W}\right)$ foi registrado entre 1997 e 1999. Apenas uma embarcação foi amostrada no litoral sul do Estado de São Paulo (região de Cananéia), a qual pratica pesca com características industriais, podendo operar até 40 milhas náuticas da costa. A mortalidade média de toninhas acidentalmente capturadas pela embarcação amostrada foi de 11 exemplares/ano, com uma proporção de sexos de 2,3 machos para cada fêmea. Diversas comunidades de pescadores artesanais foram amostradas no litoral do Estado do Paraná, onde as pescarias, em geral, não ultrapassam as 5 milhas náuticas da costa. Uma mortalidade média de 10 toninhas/ano foi estimada nesse Estado. Não foi observada diferença significativa $(P>0,05)$ na proporção de machos e fêmeas acidentalmente capturados pelas pescarias artesanais do Estado do Paraná. A proporção de toninhas sexualmente imaturas alcançou $55 \%$ no sul do Estado de São Paulo, contra 76,2\% no litoral do Estado do Paraná. As redes de emalhe de fundo, com malha de 7,0 e de 13,0cm entre nós opostos foram as que registraram o maior número de toninhas acidentalmente capturadas na região de Cananéia. No litoral do Estado do Paraná, as artes de pesca que acidentalmente capturaram o maior número de toninhas foram as redes de superfície com malha de 10,0 cm entre nós opostos. Comparando esses tamanhos de malha com aqueles apresentados na literatura sobre capturas acidentais de toninhas em outras localidades, aparentemente as características das pescarias (i.e. distância da costa, profundidade, esforço de pesca e época do ano) são mais importantes no que diz respeito a capturas acidentais dessa espécie do que o tamanho de malha propriamente dito. O predomínio de machos capturados nas pescarias mais distantes da costa, e o maior número de toninhas sexualmente imaturas nas capturas acidentais mais próximas da costa, sugerem segregação espacial entre algumas classes etárias e sexo nessa espécie na área de estudo. Os resultados também sugerem que as pescarias com características de pesca industrial, praticadas pelas embarcações na região de Cananéia, podem estar causando forte impacto nas populações de $P$. blainvillei, tornando necessária a continuidade do monitoramento das atividades de pesca por um período maior, incluindo o maior número de embarcações possíveis, para certificação das estimativas de mortalidade naquela região.

Keywords: Pontoporia blainvillei, Fishery interactions, By-catch, Brazil.

\section{Introduction}

Incidental catches of franciscana (Pontoporia blainvillei) are known throughout its distribution (Brownell, 1975; Pinedo, 1986; Pérez-Macri and Crespo, 1989; Corcuera, 1994; Siciliano, 1994; Pinedo, 1994a; Praderi, 1997; Moreno et al., 1997; Zanelatto, 1997; Secchi et al., 1997a; Di Beneditto et al., 1998; Rosas, 2000; Bertozzi and Zerbini, 2002; Santos et al., 2002) and are certainly an enormous threat to this species. On the southern coast of Rio Grande do Sul State, the mortality of franciscanas in coastal gillnets was estimated at 460 individuals/year (Secchi et al., 1997a). According to Secchi (1999) and Secchi et al. (2000), the population in that area will collapse if current levels of by-catch continue, and it is urgent to implement immediate management action to preserve the species. Concerning the northern form of $P$. blainvillei, distributed north of $27^{\circ} \mathrm{S}$, Di Beneditto et al. (1998) presented data on the franciscana fishery interactions off the coast of Rio de Janeiro State, including fishery characteristics and catch per unit of effort (CPUE). Bertozzi

\footnotetext{
1 Instituto Nacional de Pesquisas da Amazônia (INPA), Laboratório de Mamíferos Aquáticos. Caixa Postal 478, Manaus, AM, 69011-970, Brazil

${ }^{2}$ Universidade Federal do Paraná (UFPR), Departamento de Zoologia. Caixa Postal 19020, Curitiba, PR, 81531-970, Brazil.

${ }^{3}$ Centro de Estudos do Mar/UFPR, Pontal do Sul, Pontal do Paraná, PR 83255-000, Brazil.

- Corresponding author: frosas@inpa.gov.br.
} 
and Zerbini (2002) presented data on fishery interactions of franciscanas off the northern coast of São Paulo State, with a total of 25 individuals incidentally caught in less than two years. According to the latter authors, due to the large number of fishing communities yet to be monitored, franciscana mortality in this area can be substantially higher.

Information about franciscanas incidentally caught off southern São Paulo and Paraná states have previously been analyzed by Schmiegelow (1990) and Zanelatto (1997), who based their studies mainly on stranded carcasses recovered from the beaches.

In this study, individuals of $P$. blainvillei incidentally caught on the southern coast of São Paulo State (Cananéia region) and the coast of Parana State $\left(25^{\circ} 00^{\prime}-25^{\circ} 58^{\prime} S\right)$, were analyzed. The main objective was to describe the fishery characteristics, number of animals caught per year, proportions of sexes and sexual maturity of the franciscanas captured.

\section{Material and Methods}

From January to June 1997, an information network was set up with the artisanal fishing communities of Vila da Barra do Superagüi, Ilha das Peças, and the beaches located between Pontal do Sul and Matinhos (25ำ' $48^{\circ} 05^{\prime} \mathrm{W}$ and $25^{\circ} 58^{\prime} \mathrm{S}, 48^{\circ} 35^{\prime} \mathrm{W}$ ) on the coast of Paraná State (Fig. 1). The number of incidental captured franciscana on the southern coast of São Paulo State (region of Cananéia) $\left(25^{\circ} 00^{\prime} \mathrm{S}, 47^{\circ} 54^{\prime} \mathrm{W}\right.$ and $25^{\circ} 04^{\prime} \mathrm{S}$, $47^{\circ} 56^{\prime} \mathrm{W}$ ) (Fig. 1) was obtained from only one commercial gillnet fishing boat monitored. For both regions, the fishermen were asked to make contact whenever they found a dead dolphin on the beaches and every time a franciscana incidentally died in their fishing nets. The present study analyzed franciscanas incidentally caught between July 1997 and June 1999 for Paraná region and from January 1998 to October 1999 for southern São Paulo. In order to characterize the fishery, information on the time of year, target species, position of the nets in the water, stretched mesh size (distance between opposite knots), size of the nets, distance from the coast, fishing area, number of nets in the community and the vessel horsepower were recorded. The fishing effort in the study area could not be estimated. Most of the time, especially during the first year of the study, fishermen were not confident enough to provide data on fishing effort, despite bringing the incidentally caught dolphins. Therefore we concentrated the field effort on the collection of biological material.

With the aim of verifying the sexual proportions of individuals incidentally caught, the sex of each specimen was recorded and the proportions analyzed by means of the Chi-square test $\left(\chi^{2}\right)$, using Yates' correction for continuity $\left(\chi_{\mathrm{c}}^{2}\right)$, assuming as a null hypothesis a sexual proportion of 1:1.

The gonads were analyzed macro- and microscopically in order to determine the sexual maturity of the animals

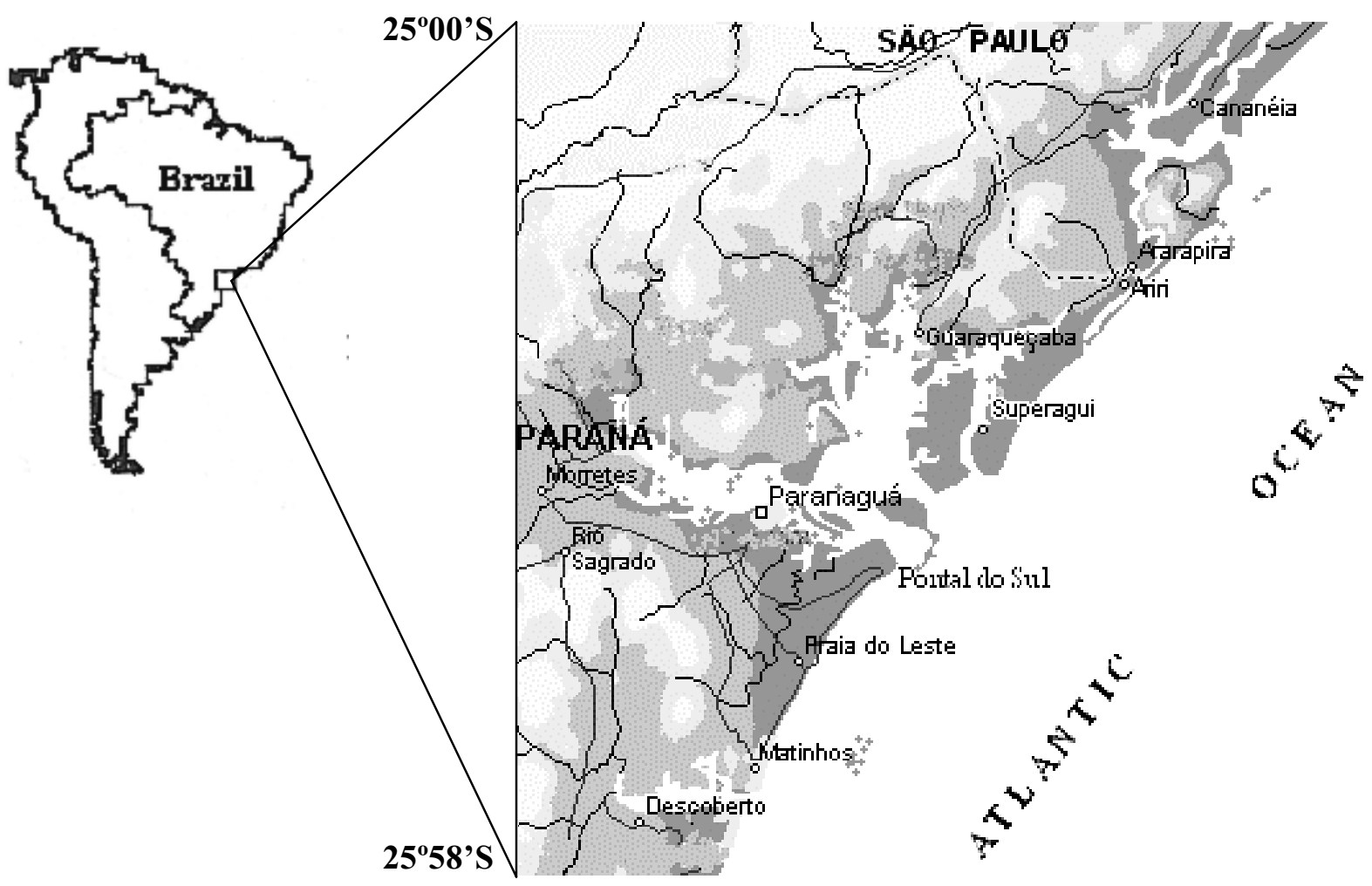

Figure 1. Map of study area. The coast of Paraná and southern São Paulo states are shown in detail. 
incidentally caught in the nets. For the histological analyzes, the gonads were fixed in a solution of $80 \%$ alcohol, $40 \%$ formaline, and glacial acetic acid, in the proportion of $85: 10: 5$. After a period of $24 \mathrm{hrs}$ in this solution, the gonads were transferred to $70 \%$ alcohol, where they remained until histological preparation. The slides were prepared according to the technique described by Beçak and Paulete (1976), with a thickness of $6 \mu \mathrm{m}$ and stained with Hematoxilin and Eosin (HE) and Masson's Trichrome methods.

\section{Results}

\section{Fishery Characteristics}

The boat operating from Cananéia is not artisanal. It is $18 \mathrm{~m}$ long and usually has four men aboard. The engine is of $115 \mathrm{hp}$ and trips can last up to 15 days. The nets are set between 10 and 20 nautical miles $(\mathrm{nm})$ from the coast, but occasionally they are set up to $40 \mathrm{~nm}$ from the shore. The main target species are small sharks (Mustelus sp. and Rhizoprionodon lalandei), sciaenids (Macrodon ancylodon, Menticirrhus sp., Cynoscion sp., Larimus breviceps and Micropogonias furnieri), largehead hairtail (Trichiurus lepturus), Atlantic leatherjacket (Oligoplites sp.) and spotted mackerel (Scomberomorus sp.). The characteristics of the fishing nets used by the boat are shown in Table 1.

All the franciscanas incidentally caught on the Paraná coast came from artisanal fisheries. The fishing boats have an average length of 7 to $10 \mathrm{~m}$, usually operated by two fishermen. The engines of the fishing boats vary from 11 to 36hp and the boats usually start their fishing activities at dawn (05h00-06h00) and return at the end of the afternoon on the same day (16h00-18h00). Fishing activities usually occur up to $5 \mathrm{~nm}$ from the beach.
The most important artisanal fishery on the Paraná coast concentrates on shrimps (Corrêa et al., 1996; Lana et al., 2000). The main target species in the marine coastal area are Atlantic seabob (Xiphopenaeus kroyeri) and southern white shrimp (Litopenaeus schmitti), caught throughout the year, except during the protection period decreed by IBAMA (Instituto Brasileiro do Meio Ambiente e dos Recursos Naturais Renováveis), between February 15 and May 15 (G. Vivekananda, pers. comm.). Fishing activities in the estuarine waters of Paranaguá Bay target two other species of shrimps: the redspotted shrimp (Farfantepenaeus brasiliensis) and the pink shrimp (Farfantepenaeus paulensis). The shrimp fishery operates mainly with trawl nets (in coastal waters) and castnets (in bays), with no record in either case of incidental catches of cetaceans.

Capture of catfish (Ariidae) and seatrout (Cynoscion sp.) occurs throughout the year, usually using longline for catfish and drift gillnets with a stretched mesh size of $6.0 \mathrm{~cm}$ for Cynoscion sp. Beach seine nets, with stretched mesh sizes between 6.0 and $8.0 \mathrm{~cm}$, are used from the coast to catch mullets (Mugil sp.), especially between May and June. Drift gillnets, with a stretched mesh size of $10.0 \mathrm{~cm}$, are used from May to July to catch spotted mackerel (Scomberomorus sp.) and Atlantic leatherjacket (Oligoplites sp.), and in summer (December to March) to catch small sharks (Rhizoprionodon lalandei and Mustelus sp.). Gillnets with a stretched mesh size of $14.0 \mathrm{~cm}$ are occasionally used to catch small sharks and can be set either at the surface (driftnets) or on the sea-bed (bottom-set).

Bottom-set gillnets, with a stretched mesh size of $18.0 \mathrm{~cm}$, are set to catch common snook (Centropomus undecimalis) from October to January. Flat fish (Paralichthys orbignyana and Paralichthys tropicus) are caught mainly between June and August. This fishery uses bottom-set gillnets with a stretched mesh size between 20.0 and $22.0 \mathrm{~cm}$. These same

Table 1. Description of gillnets and main target species of fisheries practiced by the sampled boat in southern São Paulo State (Cananéia region), southeastern Brazil.

\begin{tabular}{lccc}
\hline Net characteristics & Bottom-set & Driftnet & Bottom-set \\
\hline \hline Stretched mesh size $(\mathrm{cm})$ & 7.0 & 12.0 & 13.0 \\
Net length $(\mathrm{m})$ & Up to 6000 & Up to 2000 & Up to 3000 \\
Net height $(\mathrm{m})$ & 5 & 10 to 12 & 5 to 10 \\
Twine diameter $(\mathrm{mm})$ & 0.40 & 0.60 & 0.60 \\
Net position in the water & Bottom & Surface & Bottom \\
Distance from the coast $(\mathrm{nm})$ & Up to 40 & Up to 20 & Up to 40 \\
Period of fishing & All year & May to July & All year \\
& Cynoscion sp. & & Rhizoprionodon lalandei \\
& Macrodon ancylodon & Menticirrhus sp. & Mustelus sp. \\
Target species & Trichiurus lepturus & Scomberomorus sp. & Oligoplites sp. \\
& Larimus breviceps \\
Mustelus sp. & Micropogonias furnieri
\end{tabular}


Table 2. Description of gillnets and main target species of fisheries which incidentally caught franciscanas on the coast of Paraná State, southern Brazil.

\begin{tabular}{|c|c|c|c|c|}
\hline Net characteristics & Driftnet & Driftnet/Bottom-set & Bottom-set & Bottom-set \\
\hline Stretched mesh size $(\mathrm{cm})$ & 10.0 & $10.0-14.0$ & 6.0 & $20.0-22.0$ \\
\hline Net length (m) & Up to 1200 & 1200 & 650 & Up to 1100 \\
\hline Net height (m) & 10.0 to 12.0 & 8.0 to 10.0 & 2.0 & 3.0 \\
\hline Twine diameter (mm) & 0.50 & 0.50 & $0.30-0.40$ & $0.40-0.50$ \\
\hline Position of net & Surface & Surface and Bottom & Surface & Bottom \\
\hline Distance from the coast $(\mathrm{nm})$ & Up to 5 & Up to 5 & Up to 3 & Up to 5 \\
\hline Period of fishing & $\begin{array}{l}\text { May to July* } \\
\text { Nov to Mar ** }\end{array}$ & Nov to Mar & Jan to Dec & Jun to Sept \\
\hline Target species & $\begin{array}{c}\text { Scomberomorus sp.* } \\
\text { Oligoplites sp.* } \\
\text { Rhizoprionodon lalande } i^{* *} \\
\text { Mustelus sp.** }\end{array}$ & $\begin{array}{l}\text { Rhizoprionodon lalandei } \\
\text { Mustelus sp. }\end{array}$ & Cynoscion sp. & $\begin{array}{c}\text { Paralichthys orbignyana } \\
\text { Paralichthys tropicus } \\
\text { Micropogonias furnieri } \\
\text { Squatina sp. }\end{array}$ \\
\hline
\end{tabular}

nets are also used to catch croakers (Micropogonias furnieri) and angel shark (Squatina sp.). Grouper (Epinephelus sp.), cobia (Rachycentron canadus), and sharks (Galeocerdo cuvieri, Engomphodus taurus and Sphyrna sp.) are caught, especially in the summer months (December to March), using bottom-set gillnets with stretched mesh sizes varying from 35.0 to $45.0 \mathrm{~cm}$. The main characteristics of the fishing nets used on the Paraná coast that involved incidental catches of franciscanas are shown in Table 2.

\section{Incidental Catches}

A total of 40 individuals of $P$. blainvillei incidentally caught in fishing nets were recorded. Of these, 20 came from the Cananéia region and 20 came from the Paraná coast.

In the Cananéia area, the bottom-set gillnets, with stretched mesh sizes of 7.0 and $13.0 \mathrm{~cm}$, were responsible for $90 \%$ of the by-catch. Eleven individuals were incidentally caught during the first year sampled, and nine during the second year. The estimated annual by- catch of franciscana from the boat sampled was of about 11 (i.e. 20 animals in 22 months). Sixty percent were captured between September and November (austral spring). The proportion of sexes was significantly different $\left(\chi_{c}^{2}=4.05\right.$; d.f. $\left.=1 ; \mathrm{P}<0.05\right)$, with a ratio of 2.3 males for every female. The total proportion of sexually immature franciscanas was $55 \%$. Among the immatures, males and females accounted for $64.3 \%$ and $33.3 \%$, respectively (Fig. 2A). Most of the incidental catches $(63.3 \%)$ involved more than one individual. In $45.4 \%$ of the cases, the capture involved two individuals. Capture of one and three individuals represented $36.4 \%$ and $18.2 \%$, respectively.

On the Paraná coast, the numbers of incidentally caught franciscanas were 14 and six for the first and second years of sampling, respectively, with the captures distributed in a similar way throughout the year. The estimated annual by-catch was 10 franciscanas. Driftnets with a stretched mesh size of $10.0 \mathrm{~cm}$ were responsible for most of the incidental catches of franciscanas, accounting for $38.5 \%$ of
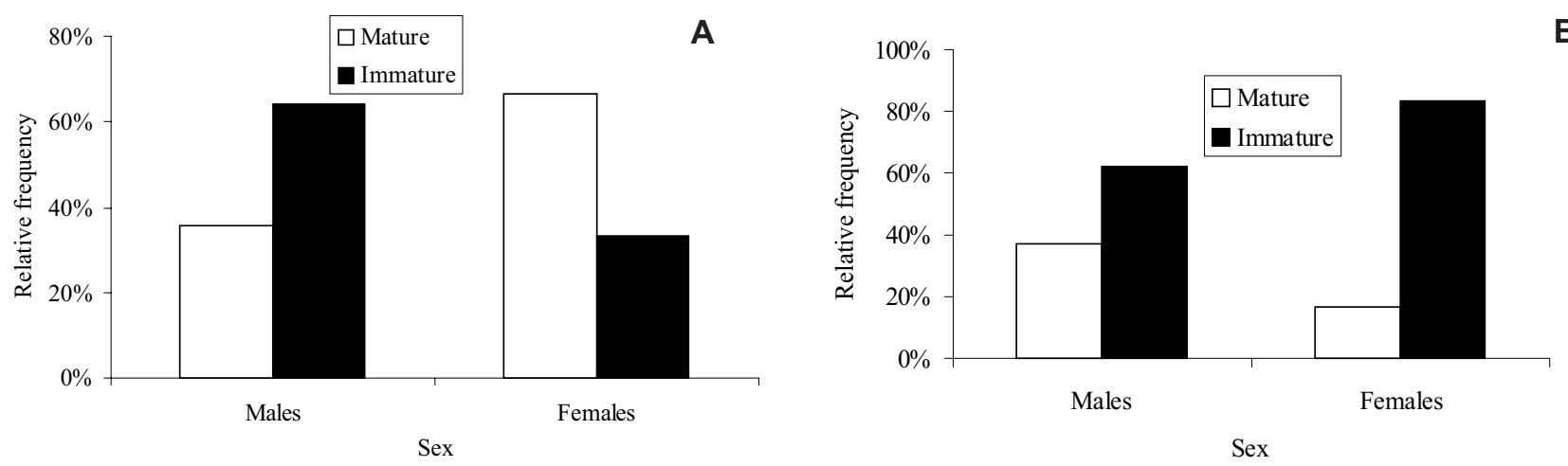

Figure 2. Sexual maturity of male and female Pontoporia blainvillei incidentally caught in the Cananéia region (southern São Paulo State) between 1998 and 1999 (A), and off the Paraná coast between 1997 and 1998 (B). 


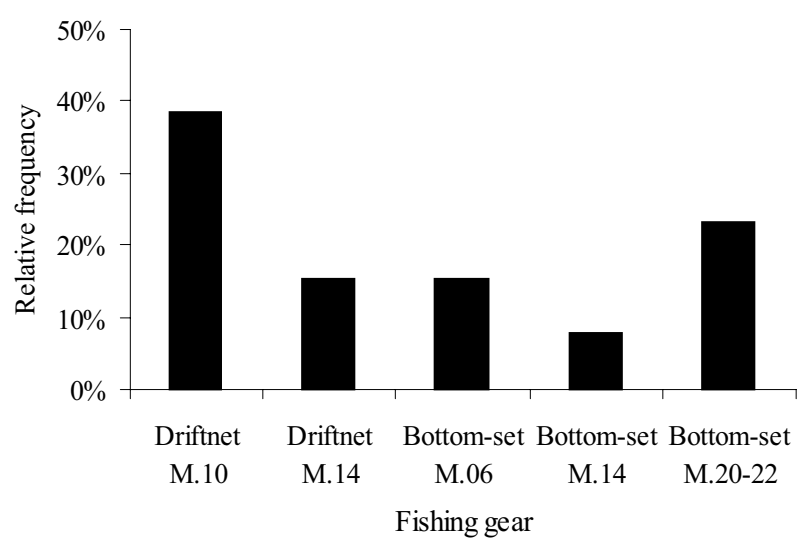

Figure 3. Relative frequency of incidentally captured Pontoporia blainvillei off the Paraná State coast, by fishing gear. The letter "M" indicates the stretched mesh size between opposite knots, in centimeters.

by-catch (Fig. 3). Bottom-set gillnets for flat fish, with stretched mesh sizes from 20.0 to $22.0 \mathrm{~cm}$, caused the death of $23.1 \%$ of the franciscanas analyzed (Fig. 3). Driftnets (stretched mesh size of 10.0 and $14.0 \mathrm{~cm}$ ) caught approximately $55 \%$ of the franciscanas. The proportion of males and females incidentally caught in this area was not significantly different from 1:1 $\left(\chi_{c}^{2}=0.45 ;\right.$ d.f. $\left.=1 ; \mathrm{P}>0.05\right)$. Of the 20 franciscanas incidentally caught, $75 \%$ were sexually immature, of which $62.5 \%$ were males and $83.3 \%$ were females (Fig. 2B). All incidental catches of $P$. blainvillei involved only one individual per net. However, on one occasion a franciscana and an estuarine dolphin (Sotalia guianensis) were caught simultaneously in a bottom-set gillnet with a stretched mesh size of $14.0 \mathrm{~cm}$, set for small sharks.

The distinct characteristics of the fishery off the Paraná coast (up to $5 \mathrm{~nm}$ from the coast) and in the Cananéia region (up to $40 \mathrm{~nm}$ from the coast) also resulted in a differential mortality in the incidental catches of franciscanas. Of the total number of immature animals recorded, $60 \%$ were caught off the Paraná coast. On the other hand, the fishing boat in the Cananéia region incidentally caught $64.3 \%$ of the mature individuals.

\section{Discussion}

The nets that caused the greatest incidental catches of $P$. blainvillei in the Cananéia region were the bottom-set gillnets, with stretched mesh sizes of 7.0 and $13.0 \mathrm{~cm}$, usually set further than $10 \mathrm{~nm}$ from the coast. These were the most frequently used nets by the boat sampled in that region, but not necessarily the ones with the greatest catch rates. Fishing activities in this region are not considered artisanal and are more similar to those carried out off the coast of Rio Grande do Sul State, where bottom-set gillnets cause high mortality of franciscana (Moreno et al., 1997; Secchi et al., 1997a).

Off the Paraná coast, driftnets with a stretched mesh size of $10.0 \mathrm{~cm}$ caught the largest number of $P$. blainvillei. However, these were also the nets most frequently used by the fishing communities. As for the Cananéia region, estimating the fishing effort for each type of fishing net is required to properly assess the relative threat between net types. The proportion of franciscana caught in each net type differs slightly from a previous study. According to Zanelatto (1997), bottom-set nets were responsible for $58.3 \%$ of the captures. Our data revealed that these nets and driftnets captured $45 \%$ and $55 \%$ of the franciscanas analyzed, respectively. The difference, however, is small, and might be related either to the sample size or to temporal variation in fishing effort.

According to Praderi et al. (1989), large mesh size nets (from 30 to $34 \mathrm{~cm}$ ) are more dangerous for franciscana populations in Uruguay and Argentina. Although artisanal fishermen set large mesh-sized nets ( 35 to $45 \mathrm{~cm}$ ) for sharks off Paraná State, during summer months, no franciscana by-catch was reported in these nets. Captures occurred only in nets with mesh sizes ranging from 6 to $22 \mathrm{~cm}$. Secchi et al. (1997a) showed that bottom-set gillnets with relatively small mesh sizes of 9 to $16 \mathrm{~cm}$ are responsible for a high by-catch rate of franciscana off Rio Grande do Sul State. It is possible that, in the case of incidental catches of $P$. blainvillei off Paraná and southern São Paulo states, the fishing site, depth, fishing effort and season are more important than the mesh size of the nets. However, this hypothesis needs to be tested through analyzes of catch rates of each net type, corrected by effort.

In waters off Rio Grande do Sul State and Uruguay, Pinedo (1994b) reported that between $67 \%$ and $73 \%$ of the franciscanas incidentally caught were juveniles (less than 4 years old, with the one-year age class being prevalent), and that these proportions were reasonably constant over time (1969-1982). According to the same author, populations from Uruguay present an apparently constant age distribution at different distances from the coast and different depths. However, according to Secchi et al. (1997b) and Secchi (1999), there is a difference in the average depth of incidental catches of adult male and female franciscanas off the Rio Grande do Sul coast, with captures occurring at $31 \mathrm{~m}$ and $22 \mathrm{~m}$ of depth, respectively. Although the small 
sample size in our study rules out a definite conclusion, the results suggest a certain degree of spatial segregation, with sexually immature individuals occurring mainly at distances up to $5 \mathrm{~nm}$ from the coast (State of Paraná), with an increase in the incidental catches of sexually mature individuals at distances greater than 10nm from the coast (southern São Paulo State). Similarly, the predominance of males incidentally caught in the latter area suggests a segregation of sexes, with a greater number of males at distances beyond $10 \mathrm{~nm}$ from the coast in the study area. This is also corroborated by the predominance of males in simultaneous catches observed in Cananéia.

The fact that most of the franciscanas incidentally caught in the study area were sexually immature is less worrying than if most of them were mature. It is known that the mortality of mature females, which actively participate in reproduction, has more harmful effects to the populations than the mortality of immature individuals (Gearin et al.,1994, Slooten et al., 2000). However, the incidental catches of franciscanas in the Cananéia region seem to deserve special attention. The mortality in that location reached 11 animals/year, from only one fishing boat. Approximately 30 boats operate in that region, using similar nets. Assuming that all of them operate in the same fishing area, during the same time of the year, with a similar fishing effort, it would be reasonable to assume that the catch rate is also similar. If so, the potential annual mortality of franciscanas in this region would be close to 330 animals. Although the reproductive rate of P. blainvillei is considered relatively high among odontocete species (Harrison et al., 1981; Danilewicz et al., 2000), potential mortality levels are very high and may drive the population to a decline if the population size is not large enough to sustain the removal rates. Therefore, we recommend a thorough and systematic monitoring of the fishing activities along the southern São Paulo coastal area, including as many boats as possible, in order to estimate the total by-catch. If necessary, conservation methods for reducing incidental catches of this species in the region should also be adopted.

Off the Paraná coast, Zanelatto (1997) reported 24 individuals of $P$. blainvillei incidentally caught during a seven-year period (1989 to 1995), averaging only 3.4 animals/year - approximately one third of the values obtained in this study based on data collected between 1997 and 1999. According to Lana et al. (2000), there is evidence that overall landings of artisanal fisheries are decreasing in the region. Rosas (2000) observed an increasing tendency of artisanal fishermen in Paraná to abandon fishing and turn their attention to regional tourism. There is no evidence of increased fishing effort in the area, and the difference between the two studies can be due to differences in methodology. Zanelatto (1997) based her work on stranded animals or interviews with fishermen, without an intensive effort for recovering dolphins incidentally caught. However, it is also possible that the difference may reflect a real increase in franciscana by-catch.
Even if the latter hypothesis is correct, the total incidental catches off the Paraná coast are still relatively modest. About $40 \%$ of the fishing boats were monitored in that area, resulting in an estimated annual mortality of 10 individuals. All boats have similar fishing nets. Assuming that they operate at similar distances from the coast, during the same period, with a similar fishing effort, the total annual by-catch along the Paraná coast can be of about 25 franciscanas.

\section{Acknowledgements}

We sincerely thank the fishermen of Vila da Barra do Superagüi and Ilha das Peças (Paraná coast) for the information provided and help in collecting the incidentally caught individuals, and Instituto de Pesquisas Cananéia (IPeC) for assistance in collecting the franciscanas incidentally caught off the southern coast of São Paulo. Financial support from Fundação O Boticário de Proteção à Natureza and the MacArthur Foundation is gratefully acknowledged. We also thank IBAMA/PR, especially Guadalupe Vivekananda, head of Parque Nacional do Superagüi. Part of this study was developed in the laboratories of the Centro de Estudos do Mar/UFPR. We also thank Kesä K. Lehti for translating the manuscript from Portuguese to English. Eduardo Secchi and Fernanda Marques reviewed the manuscript and provided useful comments to improve it. Coordenação de Pessoal de Nível Superior (CAPES) provided a fellowship to F.C.W.R. This study is part of a dissertation presented by Fernando C. Weber Rosas, submitted in partial fulfillment for a PhD degree in Zoology at Universidade Federal do Paraná (UFPR), Curitiba, Brazil.

\section{References}

Beçak, W. and Paulete, J. (1976) Técnicas de Citologia e Histologia. Vol. 1. Livros Técnicos e Científicos Editora S.A., Rio de Janeiro.

Bertozzi, C.P. and Zerbini, A.N. (2002) Incidental mortality of franciscana, Pontoporia blainvillei, in the artisanal fishery of Praia Grande, São Paulo State, Brazil. The Latin American Journal of Aquatic Mammals (special issue) 1: 153-160.

Brownell, R.L. (1975) Progress report on the biology of the franciscana dolphin, Pontoporia blainvillei, in Uruguayan waters. Journal of the Fisheries Research Board of Canada 32: 1073-1078.

Corcuera, J. (1994) Incidental mortality of franciscanas in Argentine waters: The threat of small fishing camps. Pages 291-294 in Perrin, W.F., Donovan, G.P. and Barlow, J. (Eds) Gillnets and cetaceans. International Whaling Commission (special issue 15), Cambridge.

Corrêa, M.F.M., Pinheiro, P.C., Barros-Lemos, P.H. and Pinto, E.F. (1996) Diagnóstico da Pesca da APA de Guaraqueçaba in Angulo, R.J. (Ed.) Zoneamento Econômico-Ecológico da APA de Guaraqueçaba. (Unpublished).

Danilewicz, D.S., Secchi, E.R., Ott, P.H. and Moreno, I.B. (2000) Analyses of the age at sexual maturity and reproductive rates of franciscanas (Pontoporia blainvillei) from Rio Grande do Sul, southern Brazil. Comunicações do Museu de Ciências e Tecnologia. PUCRS 13: 89-98.

Di Beneditto, A.P.M., Ramos, R.M.A. and Lima, N.R.W. (1998) Fishing activity in northern Rio de Janeiro State (Brazil) and its 
relation with small cetaceans. Brazilian Archives of Biology and Technology 41 (3): 296-302.

Gearin, P.J., Melin, S.R., Delong, R.L., Kajimura, H. and Johnson, M.A. (1994) Harbour porpoise interaction with chinook salmon set-net fishery in Washington State. Pages 427-438 in Perrin, W.F., Donovan, G.P. and Barlow, J. (Eds) Gillnets and cetaceans. International Whaling Commission (special issue 15), Cambridge.

Harrison, R.J., Bryden, M.M., McBrearty, D.A. and Brownell, R.L. (1981) The ovaries and reproduction in Pontoporia blainville (Cetacea: Platanistidae). Journal of Zoology 193: 563-580.

Lana, P.C., Marone, E., Lopes, R.M. and Machado, E.C. (2000) The subtropical estuarine complex of Paranaguá Bay, Brazil. Pages 131-145 in Seeliger, U., Lacerda, L.D. and Kjerfve, B. (Eds) Ecological Studies, 144 - Coastal Marine Ecosystems of Latin America. Springer-Verlag Berlin Heidelberg.

Moreno, I.B., Ott, P.H. and Danilewicz, D.S. (1997) Análise preliminar do impacto da pesca costeira sobre Pontoporia blainvillei no litoral norte do Rio Grande do Sul, Brasil. Pages 31-41 in Pinedo, M.C. and Barreto, A.S. (Eds) Anais do 2" Encontro sobre Coordenação de Pesquisa e Manejo da Franciscana. Ed. FURG, Rio Grande.

Pérez-Macri, G. and Crespo, E.A. (1989) Survey of the franciscana, Pontoporia blainvillei, along the Argentine coast, with preliminary evaluation of mortality in coastal fisheries. Pages 57-63 in Perrin, W.F., Brownell, R.L., Kaiya, Z. and Jiankang, L. (Eds) Biology and conservation of the river dolphins. Occasional Papers of the IUCN, N 3, IUCN/SSC, Gland.

Pinedo, M.C. (1986) Mortalidade de Pontoporia blainvillei, Tursiops gephyreus, Otaria flavescens $e$ Arctocephalus australis na costa do Rio Grande do Sul, Brasil, 1976-1983. Pages 187-199 in Castello, H.P. and Ruth, I. (Eds) Anais I Reunión de Trabajo de Expertos en Mamíferos Acuáticos de América del Sur, Buenos Aires.

Pinedo, M.C. (1994a) Review of small cetacean fishery interactions in southern Brazil with special reference to the franciscana, Pontoporia blainvillei. Pages 251-259 in Perrin, W.F., Donovan, G.P. and Barlow, J. (Eds) Gillnets and cetaceans. International Whaling Commission (special issue 15), Cambridge.

Pinedo, M.C. (1994b) Impact of incidental fishery mortality on the age structure of Pontoporia blainvillei in southern Brazil and Uruguay. Pages 261-264 in Perrin, W.F., Donovan, G.P. and Barlow, J. (Eds) Gillnets and cetaceans. International Whaling Commission (special issue 15), Cambridge.

Praderi, R. (1997) Análisis comparativo de estadísticas de captura y mortalidad incidental de Pontoporia blainvillei en Uruguay durante 20 años. Pages 42-53 in Pinedo, M.C. and Barreto, A.S. (Eds) Anais do $2^{\circ}$ Encontro sobre Coordenação de Pesquisa e Manejo da Franciscana. Ed. FURG, Rio Grande.

Praderi, R., Pinedo, M.C. and Crespo, E.A. (1989) Conservation and management of Pontoporia blainvillei in Uruguay, Brazil and Argentina. Pages 52-56 in Perrin, W.F., Brownell, R.L., Kaiya, Z. and Jiankang. L. (Eds) Biology and conservation of the river dolphins. Occasional Papers of the IUCN, N³, IUCN/SSC. Rosas, F.C.W. (2000) Interaçôes com a pesca, mortalidade, idade, reprodução e crescimento de Sotalia guianensis $e$ Pontoporia blainvillei (Cetacea, Delphinidae e Pontoporiidae) no litoral sul do Estado de São Paulo e litoral do Estado do Paraná, Brasil. PhD Thesis. Universidade Federal do Paraná, Curitiba. 145pp.

Santos, M.C.O., Vicente, A.F.C., Zampirolli, E., Alvarenga, F. and Souza, S.P. (2002) Records of franciscana (Pontoporia blainvillei) from the coastal waters of São Paulo State, southeastern Brazil. The Latin American Journal of Aquatic Mammals (special issue) 1: 169-174.

Schmiegelow, J.M.M. (1990) Estudo sobre cetáceos odontocetes encontrados em praias da região entre Iguape (SP) e Baía de Paranaguá (PR) $\left(24^{\circ} 42^{\prime} S-25^{\circ} 28^{\prime} S\right)$ com especial referência a Sotalia fluviatilis (Gervais, 1853) (Delphinidae). MSc Thesis. Universidade de São Paulo, São Paulo. 149pp.

Secchi, E.R. (1999) Taxa de crescimento potencial intrínseco de um estoque de franciscanas, Pontoporia blainvillei (Gervais \& D'Orbigny, 1844) (Cetacea, Pontoporiidae) sob o impacto da pesca costeira de emalhe. MSc Thesis. Fundação Universidade Federal do Rio Grande, Rio Grande. 152pp.

Secchi, E.R., Zerbini, A.N., Bassoi, M., Dalla Rosa, L., Möller, M.L. and Rocha-Campos, C.C. (1997a) Mortality of franciscanas, Pontoporia blainvillei, in coastal gillnets in southern Brazil: 19941995. Report of the International Whaling Commission 47: 653-658.

Secchi, E.R., Dalla-Rosa, L., Bassoi, M. and Barcellos, L. (1997b) Uma alternativa para minimizar o impacto da pesca costeira de emalhe sobre a população de toninhas, Pontoporia blainvillei (Cetacea, Pontoporiidae), no sul do Brasil. Pages 428-429 in Abstracts, VII COLACMAR - Congresso Latino-americano sobre Ciências do Mar, 22-26 September 1997, Instituto Oceanográfico da Universidade de São Paulo, São Paulo.

Secchi, E.R., Slooten, E. and Fletcher, D. (2000) Population Viability Analysis (PVA) for a franciscana stock: when is time for action? Technical Paper WP6 presented to the IV Workshop para a Coordenação da Pesquisa e Conservação da Franciscana, Pontoporia blainvillei, no Atlântico Sul Ocidental, 05-09 November 2000, Porto Alegre. 14pp.

Siciliano, S. (1994) Review of small cetaceans and fishery interactions in coastal waters of Brazil. Pages 241-250 in Perrin, W.F., Donovan, G.P. and Barlow, J. (Eds) Gillnets and cetaceans. International Whaling Commission (special issue 15), Cambrige.

Slooten, E., Fletcher, D. and Taylor, B. (2000) Accounting for uncertainty in risk assessment: case study of Hector's dolphin mortality due to gillnet entanglement. Conservation Biology 14: $1264-1270$

Zanelatto, R.C. (1997) Captura acidental de toninha Pontoporia blainvillei Gervais and D'Orbigny, 1844 (Cetacea, Pontoporiidae) no litoral do Estado do Paraná, Brasil. Pages 23-30 in Pinedo, M.C. and Barreto, A.S. (Eds) Anais do $2^{\circ}$ Encontro sobre Coordenação de Pesquisa e Manejo da Franciscana. Ed. FURG, Rio Grande. 